\title{
Stres w pracy nauczyciela - wybrane uwarunkowania
}

KEYWORDS

stress, burnout, teacher, school

\begin{abstract}
Magdalena Szczygieł, Stres w pracy nauczyciela wybrane uwarunkowania [Stress at the teacher's workplace - chosen factors]. Kultura - Społeczeństwo Edukacja nr 2(18) 2020, Poznań 2020, pp. 311-329, Adam Mickiewicz University Press. ISSN 2300-0422. DOI 10.14746/kse.2020.18.12.1.
\end{abstract}

Stress aspects still remain as an existing problem, which requires further interdisciplinary studies. Considering the strong impact of chronic exposure to psychosocial stressors at a workplace in relational and incentives contexts of undertaking professional duties, those aspects gain in importance in teachers' work. A person stays in a continuous contact with a student, parent or another teacher, and their motivation seems to be a key aspect for the entire education process. The presented article is an attempt to capture stress indicators in a teachers' work, as well as ways of dealing with them in a school reality. The article begins by highlighting the most important stress definitions, followed by a brief methodology of self-research. Then the author describes stressors present in teacher's work, which were identified in empirical studies, and ways of dealing with stress used by tested teachers. The article ends with conclusions and recommendations for further representative studies.

\section{Wprowadzenie}

Problematyka stresu stosunkowo często jest przedmiotem zainteresowania badaczy nauk społecznych i humanistycznych. Wciąż jednak pozostaje aktualnym

* ORCID: 0000-0003-3378-4879. 
problemem, który domaga się dalszych opracowań o charakterze interdyscyplinarnym. Przyjmuje się, że chroniczna ekspozycja na psychospołeczne stresory w miejscu pracy prowadzi do wielu niekorzystnych zjawisk, takich jak zaburzenia w stanie zdrowia psychicznego, rozwój chorób psychosomatycznych czy też obniżenie poziomu zadowolenia $\mathrm{z}$ wykonywanej pracy (Merecz, 2010: 23-24). Jednostkowe negatywne konsekwencje emocjonalne i zdrowotne przekładają się dalej na koszty społeczne i ekonomiczne. Dowiedziono, że chroniczny stres utrudnia nawiązywanie oraz utrzymywanie pozytywnych i satysfakcjonujących relacji z innymi ludźmi, obniża efektywność pracy, prowadzi do dużej zmienności kadr i strat powodowanych absencją chorobową.

Zauważmy, że dobrostan psychiczny nauczycieli leży szczególnie w interesie społecznym. Jest on bowiem bezpośrednio związany z jakością ich pracy na rzecz uczniów i całej społeczności lokalnej. Nawet najlepiej przygotowany merytorycznie nauczyciel będzie gorzej uczył i wychowywał, jeśli jego funkcjonowanie w pracy nie będzie optymalne. Co więcej, nauczyciel, który przeżywa problemy natury psychologicznej, może negatywnie oddziaływać na swoich uczniów, budując z nimi dysfunkcjonalne relacje. Natomiast zaangażowany i oddany swojej pracy nauczyciel może pracować bardzo efektywnie i odnosić spore sukcesy nawet wtedy, kiedy pracuje w trudnym społecznie środowisku, pełnym problemów związanych z takimi zjawiskami, jak ubóstwo czy przestępczość (Pyżalski, 2010b: 45).

Przedłożona treść artykułu stanowi próbę uchwycenia predykatorów stresu w pracy nauczyciela oraz sposobów radzenia sobie z nim w odniesieniu do rzeczywistości szkolnej. Dla jasności wywodu treść rozpocznie krótkie przedstawienie podstawowych ujęć definicyjnych stresu.

\section{Wybrane ujęcia definicyjne stresu}

W literaturze psychologicznej nie ma uniwersalnej definicji stresu. Pojęcie to zostało wprowadzone do nauki w XVII wieku w pracach brytyjskiego fizyka Roberta Hooke’a (za: Mańkowska, 2017). W latach 30. ubiegłego wieku badacze zaczęli analizować stres biologiczny w kontekście reakcji na działające bodźce. Uznali wtedy, że każdy objaw nieprzystosowania lub/i braku adaptacji był ujmowany jako wskaźnik stresu. Cannon definiował wówczas stres jako „zachowanie stanu równowagi biologicznej organizmu w postaci silnego pobudzenia układu nerwowego i endokrynologicznego, pojawiającego się w reakcji na działający na organizm określony czynnik" (Pyżalski, 2010a: 22). Jedne z pierwszych badań nad stresem zapoczątkował natomiast Selye w latach 30. XX wieku. Autor określił stres jako 
niespecyficzną reakcję organizmu na wszystkie stawiane mu wymagania (Trelak, 2001). Badacz zauważył, że stan stresu stosunkowo często pojawia się w odpowiedzi na działanie czynników psychologicznych, ujął go jako „niespecyficzną reakcję organizmu na wszelkie stawiane mu żądania, wymaganie otoczenia, związane zarówno z przyjemnymi, jak i nieprzyjemnymi dla jednostki zdarzeniami” (Łosiak, 2008: 11).

Lazarus i Falkman opracowali powszechnie obowiązujące definicje stresu. Stwierdzili, że „stres pojawia się wtedy, gdy sytuacja jest postrzegana jako udaremniająca realizację jakiegoś stanu motywacyjnego (lub potencjalnie udaremniająca), powodując wzmożenie afektu i uruchomienie procesów regulacyjnych, których celem jest opanowanie afektu oraz optymalna kontynuacja efektywnego funkcjonowania" (Trelak, 2001: 40). Natomiast zdaniem P. Zimbardo (Zimbardo, Johnson, McCann, 2010) stresem można nazwać zespół specyficznych oraz niespecyficznych reakcji, które wykazuje organizm na skutek zderzenia bodźców zakłócających równowagę i wystawiających organizm na poważną, często przekraczającą sposoby radzenia sobie jednostki ze stresem, próbę. R. Lazarus i S. Folkman (za: Trelak, 2001: 70) zwracają uwagę, że „stres psychologiczny jest to szczególny rodzaj relacji między człowiekiem a otoczeniem, które to otoczenie człowiek ocenia jako nadwyrężające (taxing) lub przekraczające jego zasoby i zagrażające (endangering) jego dobrostanowi”. Na uwagę zasługuje również definicja słownikowa określająca stres jako „psychologiczne i fizyczne obciążenie lub napięcie wywołane fizycznymi, emocjonalnymi, społecznymi, ekonomicznymi czy zawodowymi okolicznościami, zdarzeniami czy doświadczeniami, z którymi trudno sobie poradzić lub które trudno wytrzymać" (Colmac, 2009: 710).

Odnosząc się pokrótce do teorii, w ramach pojęcia stresu w literaturze przedmiotu można wyróżnić trzy podstawowe podejścia (Heszen-Niejodek, Ratajczak, 2000):

- stres jako bodziec - wydarzenie zewnętrzne lub sytuacja o określonych właściwościach;

- stres jako wewnętrzna reakcja człowieka - reakcje emocjonalne (przeżycia wewnętrzne);

- stres jako zewnętrzna reakcja organizmu.

Analizując ujęcia definicyjne, można zauważyć, że wszystkie one odnoszą się do reakcji człowieka na sytuację zewnętrzną. Wydaje się, że właśnie takie synkretyczne podejście do tego zagadnienia daje szansę całościowego uchwycenia badanego tematu. Skupienie uwagi na traktowaniu stresu jako bodźca mogłoby warunkować niedocenianie subiektywnych elementów w percepcji tych bodźców. Natomiast wyraźne umiejscowienie badań nad stresem w świecie zewnętrznym 
usprawiedliwia fakt, że jakkolwiek ludzie rozumieją zdarzenia, to jednak pewne ich rodzaje (np. śmierć bliskich, wojny) mają podobne znaczenie dla bardzo różnych ludzi - bez względu na ich wiek, płeć czy wykształcenie. Można więc znaleźć punkty wspólne zarówno w opisie reakcji na stres, jak i wyłonić czynniki predykujące jego wpływ.

Można więc krótko podsumować, że stres rozumiany jest na ogół jako odpowiedź bądź reakcja organizmu na długotrwałe działanie emocji i/lub wymagania ze strony środowiska. Wpisuje się on w sposób permanentny w życie każdego człowieka, ponieważ stanowi naturalną biologiczną reakcją na zmiany zachodzące w jego życiu oraz codzienne wyzwania - zarówno pozytywne, jak i negatywne (Heszen-Niejodek, Ratajczak, 2000).

Odnosząc problematykę stresu do rzeczywistości szkolnej i pracy nauczyciela, przeprowadzono badania wstępne do określenia czynników stresogennych oraz stylów radzenia sobie ze stresem. Podjęto również próbę wstępnego określenia poziomu stresu w odniesieniu do konkretnych wyników rzeczywistości szkolnej. Rezultaty otrzymane $\mathrm{w}$ trakcie przeprowadzonych analiz zostaną przedstawione w dalszej części artykułu.

\section{Metodologiczne podstawy badań własnych}

Badania przeprowadzone zostały w roku szkolnym 2018/2019. Próbę badawczą stanowiło 110 nauczycieli w szkołach w Małopolsce, w tym 90,9\% respondentów to kobiety, a 9,1\% - mężczyźni.

W analizach wzięto pod uwagę płeć respondentów, stopień awansu zawodowego oraz typ szkoły, w której pracują nauczyciele. Rozkład tych zmiennych przedstawia się następująco: 18,2\% respondentów to nauczyciele stażyści, 27,3\% - nauczyciele kontraktowi, 27,3\% - nauczyciele mianowani i 27,3\% - nauczyciele dyplomowani. Przeprowadzone procedury statystyczne wskazały na brak istotnej statystycznie zależności pomiędzy stopniem awansu zawodowego a stylem radzenia sobie ze stresem. Podobne rezultaty otrzymano w przypadku sprawdzenia zależności pomiędzy typem szkoły, w której podejmuje zatrudnienie badany respondent, a stylem radzenia sobie ze stresem - również brak istotnie statystycznych wyników. Dla celów analizy jakościowej ważne jest jednak przytoczenie rozkładu badanej próby ze względu na typ szkoły. Zauważmy, że w szkole podstawowej podejmuje pracę $27,3 \%$ badanych, w szkole gimnazjalnej - 13,6\%; zarówno w szkole podstawowej, jak i gimnazjalnej - 9,1\%, a w szkole ponadgimnazjalnej - 50\% respondentów. 
Do oceny czynników stresogennych w szkole wykorzystano kwestionariusz ankiety „Subiektywna ocena pracy pedagogicznej” oraz fragmenty „Inwentarza wypalenia się nauczycieli” w opracowaniu S. Korczyńskiego (2014).

Kwestionariusz składa się z 52 twierdzeń. Respondenci odpowiadali według klucza:

1. Cecha nie występuje w mojej pracy.

2. Cecha występuje, ale mi nie przeszkadza w pracy.

3. Czasami mnie to irytuje lub mi przeszkadza.

4. Dość często mnie to irytuje lub mi przeszkadza.

5. Irytuje mnie to cały czas w pracy, a nawet denerwuję się z tego powodu $\mathrm{w}$ domu.

Przykładowe twierdzenia zawarte w kwestionariuszu:

1. Obawiam się utraty pracy lub przeniesienia na inne stanowisko.

2. Bardzo łatwo w kontaktach $\mathrm{z}$ młodzieżą można popełnić błąd, co może wiązać się z określonymi konsekwencjami.

3. Nauczyciele są często zaskakiwani zmianami i przepisami.

4. Realizacja zadań dydaktycznych jest utrudniona ze względu na dużą liczbę uczniów w klasach.

Dla przejrzystości prezentacji wyników badań otrzymane rezultaty podzielono na pięć obszarów: warunki techniczne, nadzór pedagogiczny i władze oświatowe, czynniki emocjonalne, nagradzanie pracy, presję czasu. Nadano również rangi odpowiedziom, określając kolejno: „Cecha nie występuje w mojej pracy” i „Cecha występuje, ale mi nie przeszkadza w pracy” jako niski poziom danego czynnika stresogennego w pracy nauczyciela. Stwierdzenie „Czasami mnie to irytuje lub mi przeszkadza” określono jako poziom średni, natomiast stwierdzenia „Dość często mnie to irytuje lub mi przeszkadza” $\mathrm{i}$ „Irytuje mnie to cały czas w pracy, a nawet denerwuję się z tego powodu w domu" określono jako poziom wysoki w postrzeganiu wagi danego czynnika stresogennego.

Fragment „Inwentarza wypalenia się nauczycieli” stanowi natomiast uzupełnienie wyżej opisanego kwestionariusza, który pozwala określić wstępnie poziom stresu w odniesieniu do wybranych sytuacji szkolnych.

Respondenci zostali poproszeni również o wypełnienie testu „Wielowymiarowy inwentarz do pomiaru radzenia sobie ze stresem”. Jest to narzędzie oparte na samopisie, składające się z 60 stwierdzeń, na które badany odpowiada w 4-stopniowej skali. Pozwala ono na ocenę 15 strategii reagowania w sytuacjach stresowych. Strategie te to: aktywne radzenie sobie, planowanie, poszukiwanie wsparcia instrumentalnego, poszukiwanie wsparcia emocjonalnego, unikanie konkurencyjnych 
działań, zwrot ku religii, pozytywne przewartościowanie i rozwój, powstrzymywanie się od działania, akceptacja, koncentracja na emocjach i ich wyładowanie, zaprzeczanie, odwracanie uwagi, zaprzestanie działań, zażywanie alkoholu lub innych środków psychoaktywnych, poczucie humoru.

Prezentowane wyniki nie mogą podlegać generalizacji ze względu na sposób doboru próby (dobór celowy na podstawie zgłoszeń ochotników). Stanowią jednak pilotaż będący punktem wyjścia dalszych analiz prowadzonych już na próbie reprezentatywnej.

\section{Predykatory stresu w pracy nauczyciela}

Czynniki stresogenne mają silny wpływ na sposób radzenia sobie w sytuacjach trudnych. Bez wątpienia stres dotyczy również pracy nauczyciela, która obciążona jest wieloma sytuacjami mogącymi wywołać określone reakcje psychiczne i biologiczne człowieka. Traktując ogólnie predykatory stresu, można wyróżnić (Augustynek, 2009: 92):

- deprywację (pozbawienie możliwości zaspokojenia istotnych potrzeb zarówno biologicznych, indywidualnych, jak i społecznych);

- zagrożenie (groźba utraty możliwości zaspokojenia istotnych potrzeb);

- frustrację (przeszkoda na drodze do zaspokojenia istotnej potrzeby czy realizacji ważnego celu);

- ból (fizyczny i/lub psychiczny).

Uszczegóławiając jednak czynniki wywołujące stres do kontekstu pracy w szkole, należy określić, czy rzeczywiście stres w pracy jest silnie odczuwany przez nauczyciela. Dość powszechnie przyjmuje się, że środowisko szkoły, ujmowane jako „różnorodny i kompleksowy obszar doświadczeń, jako wzorzec działań, aktywności, ról oraz międzyludzkich stosunków" (Noelle, za: Smoter, Sury, 2017: 81-98), wymaga od nauczyciela konfrontacji z tym, co „inne”, „trudne”, a nawet „niemożliwe”, i wchodzenia w doświadczenia, które przekraczają posiadane aktualnie możliwości i kompetencje (Noelle, za: Smoter, Sury, 2017: 81-98). W tym kontekście warto szczególnie zwrócić uwagę na obecność stresu w codzienności nauczyciela.

Na podstawie wyników badań uzyskanych po zastosowaniu fragmentu „Inwentarza wypalenia się nauczycieli” dokonano próby określenia, na ile dostrzegają oni kwestie obecne w ich środowisku pracy jako stresogenne. Warto zwrócić uwagę na rozkład wyników uzyskany w toku przeprowadzonych analiz. 
Tabela 1. Wybrane objawy wypalenia zawodowego

\begin{tabular}{|c|c|c|}
\hline Twierdzenia & Kategorie odpowiedzi & $\% \mathrm{z} \mathrm{n}=110$ \\
\hline \multirow{2}{*}{$\begin{array}{l}\text { Praca w zawodzie nauczyciela powoduje, że czuję się emocjo- } \\
\text { nalnie wyczerpany. }\end{array}$} & bardzo rzadko/rzadko & 27,3 \\
\hline & bardzo często/często & 72,7 \\
\hline \multirow[t]{2}{*}{ Odczuwam zmęczenie przed pójściem do pracy. } & bardzo rzadko/rzadko & 45,5 \\
\hline & bardzo często/często & 54,5 \\
\hline \multirow[t]{2}{*}{ Wiele czynności zawodowych wykonuję z konieczności. } & bardzo rzadko/rzadko & 54,5 \\
\hline & bardzo często/często & 45,5 \\
\hline \multirow{2}{*}{$\begin{array}{l}\text { Odnoszę wrażenie, że osoby, z którymi pozostaję w kontaktach } \\
\text { zawodowych, nie są entuzjastycznie nastawione do mojej pracy. }\end{array}$} & bardzo rzadko/rzadko & 54,5 \\
\hline & bardzo często/często & 45,5 \\
\hline \multirow{2}{*}{$\begin{array}{l}\text { Zdarza mi się odnosić do dzieci w sposób lekceważący lub } \\
\text { poniżający. }\end{array}$} & bardzo rzadko/rzadko & 100,0 \\
\hline & bardzo często/często & 0,0 \\
\hline \multirow{2}{*}{$\begin{array}{l}\text { Praca z dziećmi (młodzieżą) jest dla mnie naprawdę stresu- } \\
\text { jąca. }\end{array}$} & bardzo rzadko/rzadko & 18,2 \\
\hline & bardzo często/często & 81,8 \\
\hline \multirow[t]{2}{*}{ Pod koniec dnia pracy w szkole czuję się wykończony. } & bardzo rzadko/rzadko & 54,5 \\
\hline & bardzo często/często & 45,5 \\
\hline \multirow[t]{2}{*}{ Coraz mniej mam chęci do pracy. } & bardzo rzadko/rzadko & 63,6 \\
\hline & bardzo często/często & 36,4 \\
\hline \multirow[t]{2}{*}{ Odczuwam niechęć do doskonalenia zawodowego. } & bardzo rzadko/rzadko & 36,4 \\
\hline & bardzo często/często & 63,6 \\
\hline \multirow[t]{2}{*}{ Czuję, że brak mi siły, by skutecznie pracować. } & bardzo rzadko/rzadko & 54,5 \\
\hline & bardzo często/często & 45,5 \\
\hline \multirow[t]{2}{*}{ Po spotkaniach z rodzicami tracę energię i zapał do pracy. } & bardzo rzadko & 100,0 \\
\hline & bardzo często/często & 0,0 \\
\hline \multirow[t]{2}{*}{ Obawiam się nieoczekiwanych reakcji, zachowań uczniów. } & bardzo rzadko/rzadko & 90,9 \\
\hline & bardzo często/często & 9,1 \\
\hline
\end{tabular}

Źródło: opracowanie własne.

Nauczyciele bardzo często lub często zwracali uwagę, że praca w zawodzie nauczyciela powoduje, że czują się emocjonalnie wyczerpani (72,7\%); dodatkowo 81,8\% nauczycieli uznało, że praca ta jest dla nich powodem do stresu. Pozostałe wyniki są szczególnie interesujące - warte weryfikacji na szerszej próbie. Świadczą o wysokim poziomie zadowolenia z pracy i poczucia dość silnej do niej motywacji. Zauważmy, że badani nauczyciele nie dostrzegają problemu w trudnościach $\mathrm{z}$ odnoszeniem się do dzieci z szacunkiem - 100\% badanych nauczycieli deklaruje, że nie odnosi się do dzieci w sposób lekceważący lub poniżający. Również 100\% badanych respondentów po spotkaniach z rodzicami nie traci energii i zapału do pracy, a 90,9\% nie obawia 
się nieoczekiwanych reakcji i zachowań uczniów. Dodatkowo 63,6\% badanych nadal ma chęć do pracy i zapał. Pojawia się niechęć do dalszego doskonalenia zawodowego $(63,6 \%)$ i odczuwanie zmęczenia przed pójściem do pracy (54,5\%). Można zatem uznać, że nauczyciele są na ogół zadowoleni ze swojej pracy i czują się do niej zmotywowani, pomimo odczuwanego napięcia emocjonalnego i stresu.

Kolejnym krokiem analizy była podjęta próba określenia predykatorów stresu w pracy nauczyciela. Przyjmując, że stresor to każdy rodzaj bodźca lub każda sytuacja, która za pośrednictwem procesów psychofizjologicznych może doprowadzić do szkody w postaci pogorszenia samopoczucia, dobrego funkcjonowania i/lub zdrowia, można uznać, że w gruncie rzeczy psychospołecznym zagrożeniem jest wszystko, co pogarsza samopoczucie lub utrudnia prawidłowe i skuteczne działanie. Jest to bardzo szeroka kategoria i intuicyjnie można wyczuć, że w zasadzie do przytoczonego opisu pasuje nieskończenie wiele sytuacji (Merecz, 2010: 23-24). Dokonano jednak próby uchwycenia tych szczególnych okoliczności, które są silnie związane z rzeczywistością szkolną. Pierwszym czynnikiem poddanym analizie jest kontrola pracy i sposób jej nadzoru.

Tabela 2. Nadzór pedagogiczny i władze oświatowe

\begin{tabular}{|l|l|c|}
\hline Twierdzenia & Poziom & $\%$ z n $=110$ \\
\hline Nierealistyczne wymagania & niski & 27,3 \\
\cline { 2 - 3 } & średni & 36,4 \\
\cline { 2 - 3 } & wysoki & 36,4 \\
\hline \multirow{2}{*}{ Obawa przed utratą pracy lub zmianą stanowiska } & niski & 81,8 \\
\cline { 2 - 3 } & średni & 18,2 \\
\cline { 2 - 3 } & wysoki & 0,0 \\
\hline \multirow{2}{*}{ Częste zmiany i zmiany przepisów } & niski & 36,4 \\
\cline { 2 - 3 } & średni & 18,2 \\
\cline { 2 - 3 } & wysoki & 45,5 \\
\hline \multirow{2}{*}{$\begin{array}{l}\text { Naciski na formalne rozliczanie się z różnych form dokształcania, bez } \\
\text { rzeczywistego podnoszenia kwalifikacji }\end{array}$} & niski & 36,4 \\
\cline { 2 - 3 } & średni & 18,2 \\
\cline { 2 - 3 } & wysoki & 45,5 \\
\hline \multirow{2}{*}{$\begin{array}{l}\text { Ustawiczna kontrola i ocena (uczniów, rodziców, przełożonych, władz } \\
\text { oświatowych) }\end{array}$} & niski & 9,1 \\
\cline { 2 - 3 } & średni & 45,5 \\
\cline { 2 - 3 } & wysoki & 45,5 \\
\hline \multirow{2}{*}{$\begin{array}{l}\text { Zbyt wygórowane wymagania wobec nauczyciela stawiane przez wła- } \\
\text { dze oświatowe }\end{array}$} & niski & 27,3 \\
\cline { 2 - 3 } & średni & 27,3 \\
\cline { 2 - 3 } & wysoki & 45,5 \\
\hline
\end{tabular}




\begin{tabular}{|l|l|r|}
\hline Nierówne traktowanie nauczycieli w przydziale zadań lub dostępności & niski & 27,3 \\
\cline { 2 - 3 } różnych środków, wyróżnień, gratyfikacji motywacyjnych itp. & średni & 18,2 \\
\cline { 2 - 3 } & wysoki & 54,5 \\
\hline Efekty pracy niezauważone przez nadzór pedagogiczny & niski & 72,7 \\
\cline { 2 - 3 } & średni & 18,2 \\
\cline { 2 - 3 } & wysoki & 9,1 \\
\hline \multirow{2}{*}{ Brak informacji co do jakości wykonywanych zadań } & niski & 63,6 \\
\cline { 2 - 3 } & średni & 27,3 \\
\cline { 2 - 3 } & wysoki & 9,1 \\
\hline \multirow{2}{*}{ Ograniczony wpływ na decyzje szkoły jako całości } & niski & 18,2 \\
\cline { 2 - 3 } & średni & 45,5 \\
\cline { 2 - 3 } & wysoki & 36,4 \\
\hline \multirow{2}{*}{ Brak poczucia niezależności } & niski & 45,5 \\
\cline { 2 - 3 } & średni & 9,1 \\
\cline { 2 - 3 } & wysoki & 45,5 \\
\hline
\end{tabular}

Źródło: opracowanie własne.

Interesujący poznawczo jest rezultat wskazujący, że nauczyciele nie odczuwają na ogół strachu przed utratą pracy $(81,8 \%$ respondentów zaznaczyło odpowiedzi świadczące o niskim poczuciu zagrożenia tym aspektem). Nie przeszkadza bądź nie występuje poczucie braku nagradzania pracy (72,7\%), czynnikiem stresogennym nie jest też brak informacji co do jakości wykonywanej pracy (63,6\%). Sytuacją problemową, potencjalnie generującą silny stres, są częste zmiany w pracy i zmiany w przepisach prawnych $(45,5 \%$ odpowiedzi świadczących o wysokim poziomie generowania sytuacji frustrującej, problemowej). Ponad połowa nauczycieli $(54,5 \%)$ dostrzega problem w nierównym traktowaniu w przydziale zadań lub dostępności różnych środków, wyróżnień, gratyfikacji motywacyjnych itp. Nauczyciele uważają za silnie zakłócające ich pracę „naciski na formalne rozliczanie się z różnych form dokształcania, bez rzeczywistego podnoszenia kwalifikacji” $(45,5 \%)$ oraz „ustawiczną kontrolę i ocenę ze strony uczniów, rodziców, przełożonych czy władz oświatowych” (45,5\%). Pozostałe czynniki mają stosunkowo umiarkowany wpływ na poziom stresu nauczyciela w pracy.

W prezentowanych już wcześniej wynikach badań obecny był silnie czynnik wyczerpania emocjonalnego, na który zwróciło uwagę 72,7\% respondentów. Wypowiedzi tych nie potwierdzają jednak te $\mathrm{z}$ nich, które uwzględniają komponent emocjonalny. Biorąc pod uwagę wyniki uzyskane przy zastosowaniu kwestionariusza „Subiektywna ocena pracy pedagogicznej”, taka ocena nie została jednak sil- 
nie podkreślona. Z kwestionariusza wybrano te czynniki, które mogą wskazywać w sposób szczególny na komponent emocjonalny. Wyniki kształtują się w sposób następujący.

Tabela 3. Czynniki emocjonalne

\begin{tabular}{|c|c|c|}
\hline Twierdzenia & Poziom & $\% \mathrm{z} \mathrm{n}=110$ \\
\hline \multirow{3}{*}{$\begin{array}{l}\text { Brak reakcji na niecenzurowane wypowiedzi uczniów w celu uniknięcia } \\
\text { wielu konfliktów }\end{array}$} & niski & 63,6 \\
\hline & średni & 9,1 \\
\hline & wysoki & 27,3 \\
\hline \multirow[t]{3}{*}{ Poważne problemy wychowawcze, trudne do przezwyciężenia } & niski & 45,5 \\
\hline & średni & 27,3 \\
\hline & wysoki & 27,3 \\
\hline \multirow[t]{3}{*}{ Poczucie, że praca zawodowa wpływa niekorzystnie na życie rodzinne } & niski & 54,5 \\
\hline & średni & 9,1 \\
\hline & wysoki & 36,4 \\
\hline \multirow{3}{*}{$\begin{array}{l}\text { Wykonywanie pracy wymaga ciągłego emocjonalnego zaangażowania } \\
\text { w sprawy uczniów }\end{array}$} & niski & 18,2 \\
\hline & średni & 54,5 \\
\hline & wysoki & 27,3 \\
\hline \multirow{3}{*}{$\begin{array}{l}\text { Poczucie niekończącego się dnia pracy ze względu na narastające prob- } \\
\text { lemy pracy zawodowej po jej zakończeniu }\end{array}$} & niski & 30,0 \\
\hline & średni & 40,0 \\
\hline & wysoki & 30,0 \\
\hline \multirow{3}{*}{$\begin{array}{l}\text { Obecność zdarzeń, które powodują przeżywanie silnych konfliktów we- } \\
\text { wnętrznych }\end{array}$} & niski & 54,5 \\
\hline & średni & 18,2 \\
\hline & wysoki & 27,3 \\
\hline \multirow[t]{3}{*}{ Poczucie niespełnionych zadań po zakończonym dniu pracy } & niski & 27,3 \\
\hline & średni & 45,5 \\
\hline & wysoki & 27,3 \\
\hline \multirow[t]{3}{*}{ Możliwość popełnienia błędu w pracy z młodzieżą } & niski & 54,5 \\
\hline & średni & 27,3 \\
\hline & wysoki & 18,2 \\
\hline
\end{tabular}

Źródło: opracowanie własne.

Nauczyciele uznali, że na ogół nie występują wcale - a jeśli występują, to nie przeszkadzają w pracy (niski poziom stresogenny) - takie czynniki, jak: brak umiejętności reakcji na niecenzurowane wypowiedzi uczniów (63,6\%); wpływ pracy na życie rodzinne (54,5\%); obecność zdarzeń, które mogą powodować 
przeżywanie silnych konfliktów wewnętrznych (54,5\%); możliwość popełnienia błędu z młodzieżą (54,5\%).

W sposób umiarkowany wpływa na poczucie napięcia emocjonalnego poczucie, że wykonywanie pracy wymaga ciągłego emocjonalnego zaangażowania w sprawy uczniów (54,5\% odpowiedzi świadczących o umiarkowanym poziomie wpływu i 27,3\% - o wysokim poziomie wpływu). Podobnie jest z poczuciem niekończącego się dnia ze względu na narastające problemy pracy zawodowej po jej zakończeniu (40\% i 30\%).

Tabela 4. Poczucie nagradzania pracy

\begin{tabular}{|c|c|c|}
\hline Twierdzenia & Poziom & $\% \mathrm{z} \mathrm{n}=110$ \\
\hline \multirow[t]{3}{*}{ Brak możliwości awansu } & niski & 63,6 \\
\hline & średni & 9,1 \\
\hline & wysoki & 27,3 \\
\hline \multirow[t]{2}{*}{ Wrażenie bycia niedocenianym } & niski & 63,6 \\
\hline & średni & 9,1 \\
\hline \multirow[t]{3}{*}{ Niskie wynagrodzenie } & niski & 27,3 \\
\hline & średni & 18,2 \\
\hline & wysoki & 54,5 \\
\hline \multirow[t]{3}{*}{ Postrzeganie pracy jako kończącej się wraz z dzwonkiem } & niski & 9,1 \\
\hline & średni & 36,4 \\
\hline & wysoki & 54,5 \\
\hline \multirow[t]{3}{*}{ Niski prestiż społeczny } & niski & 36,4 \\
\hline & średni & 0,0 \\
\hline & wysoki & 63,6 \\
\hline \multirow[t]{3}{*}{ Poczucie braku wykorzystania swoich kwalifikacji } & niski & 45,5 \\
\hline & średni & 18,2 \\
\hline & wysoki & 36,4 \\
\hline
\end{tabular}

Źródło: opracowanie własne.

Analizując dalsze rezultaty badawcze, na uwagę zasługuje fakt, że nauczyciele czują się poirytowani poczuciem niskiego prestiżu społecznego wykonywanej pracy (63,6\% odpowiedzi świadczących o wysokim poziomie problemu) oraz ponad połowa respondentów (54,5\%) - niskim wynagrodzeniem. Natomiast nie odczuwają lub odczuwają w niskim stopniu problem ewentualnych trudności z awansem $(63,6 \%)$; nie mają poczucia bycia niedocenianym w pracy $(63,6 \%)$; na ogół nie mają też poczucia braku wykorzystania swoich kwalifikacji $(45,5 \%)$. 
Tabela 5. Presja czasu

\begin{tabular}{|l|l|c|}
\hline Twierdzenia & Poziom & \% z n = 110 \\
\hline \multirow{2}{*}{ Brak czasu na rozwiązywanie problemów poszczególnych uczniów } & niski & 27,3 \\
\cline { 2 - 3 } & średni & 27,3 \\
\cline { 2 - 3 } & wysoki & 45,5 \\
\hline \multirow{2}{*}{ Brak możliwości odprężenia nawet w czasie przerwy } & niski & 22,2 \\
\cline { 2 - 3 } & średni & 33,3 \\
\cline { 2 - 3 } & wysoki & 44,4 \\
\hline \multirow{2}{*}{$\begin{array}{l}\text { Konieczność szybkiego podejmowania decyzji w sprawach wychowaw- } \\
\text { czych i reagowania na różne sygnały }\end{array}$} & niski & 9,1 \\
\cline { 2 - 3 } & średni & 27,3 \\
\cline { 2 - 3 } & wysoki & 63,6 \\
\hline \multirow{2}{*}{$\begin{array}{l}\text { Liczba przydzielonych godzin dydaktycznych znacznie przekracza obo- } \\
\text { wiązujący wymiar czasu pracy }\end{array}$} & niski & 72,7 \\
\cline { 2 - 3 } & średni & 0,0 \\
\cline { 2 - 3 } & wysoki & 27,3 \\
\hline \multirow{2}{*}{$\begin{array}{l}\text { Wykonywany zawód wymaga dużego nakładu pracy poza godzinami } \\
\text { lekcyjnymi (organizacja imprez, spotkania z rodzicami, konsultacje, } \\
\text { dodatkowe czynności wykonywane w domu itp.) }\end{array}$} & niski & 0,0 \\
\cline { 2 - 3 } & średni & 36,4 \\
\cline { 2 - 3 } & wysoki & 63,6 \\
\hline
\end{tabular}

Źródło: opracowanie własne.

W porównaniu z innymi czynnikami presja czasu jest stosunkowo silnie odczuwana przez nauczycieli. Respondenci uznali (63,6\%), że wykonywany zawód wymaga dużego nakładu pracy poza godzinami lekcyjnymi (organizacja imprez, spotkania $\mathrm{z}$ rodzicami, konsultacje, dodatkowe czynności wykonywane $\mathrm{w}$ domu itp.) i fakt ten potencjalnie generuje silny stres i napięcie. Podobnie konieczność szybkiego podejmowania decyzji w sprawach wychowawczych i reagowania na różne sygnały zaznacza się w opinii respondentów $(63,6 \%)$ jako silnie wpływająca na jakość ich pracy. Stosunkowo często $(44,4 \%)$ dostrzegają problem w braku możliwości odprężenia się $\mathrm{w}$ czasie przerw, a także brak czasu na rozwiązywanie problemów poszczególnych uczniów (45,5\%). Zauważmy, że 72,7\% respondentów nie uważa, żeby liczba przydzielonych godzin dydaktycznych znacznie przekraczała obowiązujący wymiar czasu pracy.

Kolejnym obszarem poddanym analizie były relacje w gronie nauczycielskim i kwestie relacji z rodzicami oraz uczniami. Poniższe zestawienie tabelaryczne prezentuje wybrane obszary ujęte w przeprowadzonych badaniach.

W tym obszarze nauczyciele przeważnie nie dostrzegają problemów związanych $\mathrm{z}$ wandalizmem na terenie szkoły $(63,6 \%)$ oraz rywalizacją nauczycieli $(63,6 \%)$ i ewentualnym brakiem wsparcia na wypadek trudności $(63,6 \%)$. Do- 
datkowo $81,8 \%$ nie uważa, żeby uczniowie nie reagowali pomiędzy sobą na niewłaściwe zachowania swoich kolegów. Nauczyciele twierdzą również, że atmosfera $\mathrm{w}$ gronie pedagogicznym jest na ogół sprzyjająca $(81,8 \%)$.

Tabela 6. Kwestie relacyjne

\begin{tabular}{|c|c|c|}
\hline Twierdzenia & Poziom & $\% \mathrm{z} \mathrm{n}=110$ \\
\hline \multirow{3}{*}{$\begin{array}{l}\text { Brak motywacji uczniów do nauki i lekceważący stosunek do obowiąz- } \\
\text { ków szkolnych }\end{array}$} & niski & 18,2 \\
\hline & średni & 18,2 \\
\hline & wysoki & 63,6 \\
\hline \multirow{3}{*}{$\begin{array}{l}\text { Skłonność rodziców do ujawniania postaw roszczeniowych wobec na- } \\
\text { uczycieli i szkoły }\end{array}$} & niski & 0,0 \\
\hline & średni & 0,0 \\
\hline & wysoki & 100,0 \\
\hline \multirow[t]{3}{*}{ Wandalizm na terenie szkoły } & niski & 63,6 \\
\hline & średni & 27,3 \\
\hline & wysoki & 9,1 \\
\hline \multirow{3}{*}{$\begin{array}{l}\text { Brak krytyki uczniów wobec upokarzających zachowań niektórych ko- } \\
\text { legów/koleżanek }\end{array}$} & niski & 72,7 \\
\hline & średni & 27,3 \\
\hline & wysoki & 0,0 \\
\hline \multirow[t]{3}{*}{ Rywalizacja nauczycieli } & niski & 63,6 \\
\hline & średni & 9,1 \\
\hline & wysoki & 27,3 \\
\hline \multirow[t]{3}{*}{ Atmosfera w gronie pedagogicznym nie należy do najlepszych } & niski & 81,8 \\
\hline & średni & 9,1 \\
\hline & wysoki & 9,1 \\
\hline \multirow[t]{3}{*}{ Na wypadek trudności lub kłopotów poczucie braku wsparcia kolegów } & niski & 63,6 \\
\hline & średni & 27,3 \\
\hline & wysoki & 9,1 \\
\hline
\end{tabular}

Źródło: opracowanie własne.

Zastanawiający jest fakt, że 100\% nauczycieli uważa za problem skłonność rodziców do postaw roszczeniowych wobec nauczycieli i szkoły. Dostrzegają też problemy $(63,6 \%)$ dotyczące braku motywacji uczniów i lekceważącego stosunku do obowiązków szkolnych.

Powyższe zestawienie wyników badań pokazuje, że grupa jest dość niejednorodna w swoich wypowiedziach. Bardzo mocno zaznacza się zasada, że to, co jest źródłem stresu zawodowego dla jednego pracownika, może nie stanowić żadnego problemu dla jego kolegi lub koleżanki. Psycholodzy podkreślają, że w większości 
sytuacji, z jakimi ma do czynienia człowiek w sytuacjach zawodowych czy pozazawodowych, o tym, czy zostaną one odebrane jako stresujące, decyduje przede wszystkim ich interpretacja, dlatego większość naukowców zajmujących się psychospołecznymi zagrożeniami w środowisku pracy stoi na stanowisku, że są one skutkiem wzajemnego oddziaływania warunków, wymagań, organizacji i treści pracy oraz indywidualnych potrzeb, preferencji czy właściwości pracownika (Merecz, 2010: 42). Dla jasności wywodu zdecydowano się jednak przytoczyć te czynniki, które zostały ocenione przez respondentów jako najbardziej dotkliwe w ich pracy. Są to:

- skłonność rodziców do ujawniania postaw roszczeniowych wobec nauczycieli i szkoły (100\%);

- niski prestiż społeczny $(63,6 \%)$;

- duży nakład pracy poza godzinami lekcyjnymi (organizacja imprez, spotkania z rodzicami, konsultacje, dodatkowe czynności wykonywane w domu itp.) $(63,6 \%)$;

- brak motywacji uczniów do nauki i lekceważący stosunek do obowiązków szkolnych (63,6\%);

- niskie wynagrodzenie (54,5\%);

- postrzeganie przez społeczeństwo pracy jako kończącej się wraz z dzwonkiem (54,5\%).

Wydaje się zatem, że pozytywny stosunek do pracy i zaangażowanie w przypadku nauczyciela są dość skomplikowane, przynajmniej jeśli chodzi o analizę czynników, które mają na nie wpływ. Może być tak, że nauczyciele źle oceniają formalny świat instytucji, a znacznie lepiej nieformalny świat relacji osobowych w szkole czy poczucie sensu wykonywania pracy nauczyciela. Podobne rezultaty otrzymał również w badaniach J. Pyżalski (2010b: 31-46) - 78\% badanych nauczycieli wybrałoby ponownie swój zawód. Jak więc nauczyciele radzą sobie ze stresem? Na to pytanie starano się odpowiedzieć w dalszej części artykułu.

\section{Style radzenia sobie ze stresem}

Definicja stylu radzenia sobie ze stresem to „względnie stała tendencja do stosowania w różnych sytuacjach specyficznych dla jednostki sposobów radzenia sobie, które mają na celu usunięcie lub zmniejszenie stanu stresu" (Łosiak, 2008: 79). Mogą to być: stan psychofizyczny, status społeczno-ekonomiczny, czynniki demograficzne czy też cechy osobowościowe (Strelau, Jaworska, Wrześniewski, Szczepaniak, 2005). Na ogół style radzenia sobie ze stresem możemy ujmować i rozpa- 
trywać na trzech płaszczyznach: procesu, strategii i stylu. Proces jest rozumiany jako całościowa aktywność osoby, która podejmowana jest w sytuacji stresowej. Wpływa ona na pierwotną ocenę sytuacji i jest procesem złożonym oraz dynamicznym. Strategie będące wyodrębnieniem części procesu ujmowane są jako pomniejsze aktywności, które różnią się jakościowo, tworząc określone strategie (style) radzenia sobie ze stresem. Styl ujmowany jest więc jako swoisty schemat działań, który w konfrontacji z sytuacją stresową jest automatycznie uruchamiany (Bargiel-Matusiewicz, Podbielski, Klasik, 2004: 3-4).

Na podstawie wyników zastosowanego „Wielowymiarowego inwentarza do pomiaru radzenia sobie ze stresem” wyszczególniono 15 stylów pomagających w pokonaniu go. Style podzielono za N.S. Endler i J.D.A. Parker (za: Popiel, Pragłowska, 2008). Wyróżniono:

- styl skoncentrowany na zadaniu - polega na podejmowaniu zadania; osoby wykorzystujące ten styl mają tendencję do podejmowania wysiłków zmierzających do rozwiązania problemu poprzez poznawcze przekształcenia lub próby zmiany sytuacji; główny nacisk kładziony jest na zadanie lub/i planowanie rozwiązania problemu;

- styl skoncentrowany na emocjach - polega na podejmowaniu wysiłku mającego na celu wyeliminowanie lub zmniejszenie napięcia emocjonalnego, które jest związane z przeżywaną sytuacją stresową; charakterystyczne jest to, że osoba koncentruje się na własnych przeżyciach emocjonalnych, np. poczuciu winy, złości, napięciu; pojawia się tendencja do fantazjowania i/lub myślenia życzeniowego;

- styl skoncentrowany na unikaniu - polega na podejmowaniu wysiłku, aby wystrzegać się myślenia, doświadczania i przeżywania sytuacji stresowych; przyjmować on może dwie różne formy:

a) angażowania się w czynności zastępcze, np. granie na komputerze, sen, słuchanie muzyki, myślenie o przyjemnych sprawach z przeszłości itp.;

b) poszukiwania kontaktów towarzyskich, np. spędzanie czasu z przyjaciółmi, poznawanie nowych osób.

Analizując strategie wyłonione za pomocą COPE, do strategii „skoncentrowanych na problemie" możemy zaliczyć następujące style: aktywne radzenie sobie, planowanie, poszukiwanie wsparcia instrumentalnego, poszukiwanie wsparcia emocjonalnego, unikanie konkurencyjnych działań społecznych oraz pozytywne przewartościowanie. W obrębie strategii ukierunkowanych na poszukiwanie wsparcia i koncentrację na emocjach wyróżnić można kolejnych pięć stylów radzenia sobie ze stresem, tj. zwrot ku religii, rozwój, powstrzymywanie się od działań, akceptację, koncentrację na emocjach oraz ich wyładowanie. W trzeciej 
grupie strategii, tzw. zachowań unikowych, wyróżnić można kolejnych pięć stylów radzenia sobie ze stresem: zaprzeczanie, odwracanie uwagi, zaprzestanie działań, alkohol oraz poczucie humoru. Rozkład wyników otrzymanych w toku procesu badawczego przedstawia się następująco.

Tabela 7. Style radzenia sobie ze stresem

\begin{tabular}{|c|c|c|c|}
\hline $\begin{array}{l}\text { Styl radzenia sobie } \\
\text { ze stresem }\end{array}$ & Kategoria & Średnia & $\begin{array}{l}\text { Średnia } \\
\text { całościowa }\end{array}$ \\
\hline \multirow{5}{*}{$\begin{array}{l}\text { Styl skoncentrowany } \\
\text { na zadaniu } \\
\text { (problemie) }\end{array}$} & Aktywne radzenie sobie & 3,18 & \multirow{5}{*}{3,04} \\
\hline & Planowanie & 3,30 & \\
\hline & Poszukiwanie wsparcia instrumentalnego & 3,09 & \\
\hline & Poszukiwanie wsparcia emocjonalnego & 2,82 & \\
\hline & Unikanie konkurencyjnych działań & 2,82 & \\
\hline \multirow{5}{*}{$\begin{array}{l}\text { Styl skoncentrowany } \\
\text { na emocjach }\end{array}$} & Zwrot ku religii & 2,82 & \multirow{5}{*}{2,80} \\
\hline & Pozytywne przewartościowanie i rozwój & 3,18 & \\
\hline & Powstrzymywanie się od działań & 2,73 & \\
\hline & Akceptacja & 2,44 & \\
\hline & Koncentracja na emocjach i ich wyładowaniu & 2,82 & \\
\hline \multirow{5}{*}{$\begin{array}{l}\text { Styl skoncentrowany } \\
\text { na unikaniu }\end{array}$} & Zaprzeczenie & 1,64 & \multirow{5}{*}{1,86} \\
\hline & Odwracanie uwagi & 2,27 & \\
\hline & Zaprzestanie działań & 2,20 & \\
\hline & $\begin{array}{l}\text { Zażywanie alkoholu lub innych środków psy- } \\
\text { choaktywnych }\end{array}$ & 1,45 & \\
\hline & Poczucie humoru & 1,73 & \\
\hline
\end{tabular}

Źródło: opracowanie własne.

Poddając analizie średnie wyników otrzymane na poszczególnych skalach, można uznać, że nauczyciele używają najczęściej najbardziej konstruktywnego stylu radzenia sobie ze stresem, a mianowicie w swoich działaniach zaradczych są skoncentrowani na zadaniu (średnia wyników to 3,04\% dla tego stylu), w tym najczęściej deklarują planowanie w sytuacjach trudnych (3,30\%), następnie poszukują wsparcia instrumentalnego (3,09\%), wsparcia emocjonalnego (3,82\%), a także unikają w okresie wzmożonego stresu konkurencyjnych działań.

Stosunkowo wysokie wyniki otrzymano również na skali stylu emocjonalnego. Tu szczególnie respondenci wskazywali na potrzebę pozytywnego przewartościowania sytuacji stresowej $(3,18 \%)$, a także zwrot ku religii $(2,82 \%)$. Pojawiła się też tendencja do koncentracji na trudnych emocjach i ich wyładowaniu $(2,82 \%)$, 
rzadziej powstrzymują się od jakiegokolwiek działania (2,73\%) i akceptują trudną sytuację czy wydarzenie $(2,44 \%)$.

Najrzadziej badani nauczyciele deklarują podejmowanie działań unikowych w sytuacji stresowej. Nie piją alkoholu ani nie biorą środków psychoaktywnych (średni wynik $1,45 \%$ ), na ogół też nie stosują reakcji obronnych typu zaprzeczanie (1,64\%), nie obracają też trudnych sytuacji w żart (1,73\%), sporadycznie powstrzymują się od podejmowania działań mających na celu rozwiązanie sytuacji (2,2\%), a także na ogół nie starają się odwracać swojej uwagi od problemu (2,27\%).

Trzeba stwierdzić, że nauczyciele stosują konstruktywne metody radzenia sobie w sytuacjach stresujących. Można zatem zaryzykować stwierdzenie, że pomimo napięcia emocjonalnego i stresu odczuwanego w miejscu pracy nauczyciele potrafią utrzymać w sobie pozytywny stosunek do wykonywanych obowiązków oraz motywację do pozostania w zawodzie nauczyciela właśnie ze względu na konstruktywne metody radzenia sobie w sytuacjach stresowych.

\section{Wnioski i rekomendacje do dalszych badań}

Jak pokazano wcześniej, środowisko pracy nauczyciela stanowi istotny element, który pozytywnie lub negatywnie wpływa na jego dobrostan psychiczny. Warto zatem podejmować dwa rodzaje działań: takie, w których w centrum zainteresowania znajdują się czynniki negatywne, i takie, w których trzeba się skoncentrować na czynnikach pozytywnych. W przypadku działań pierwszego rodzaju można się starać, by czynników negatywnych (obciążających) było mniej lub aby były słabiej nasilone. Oczywiście w zależności od tego, które czynniki bierze się pod uwagę, ich usunięcie może być łatwiejsze bądź trudniejsze. Jeśli chodzi o działania koncentrujące się na czynnikach pozytywnych, to ich istotą jest inicjowanie bądź wspieranie takich rozwiązań, które pozytywnie wpływają na nauczyciela: dają mu satysfakcję, budują poczucie zaangażowania w swoją pracę oraz poczucie sensu tego, co robi. Jest to podejście odmienne od tego, w którym miejsce pracy jest traktowane wyłącznie jako stresogenne, przed którym osoby pracujące w szkole muszą się bronić. Praca w tym ujęciu jest potencjalnym źródłem wielu pozytywnych doświadczeń, które stanowią źródło wartości dla wykonującego ją człowieka. Zatem najbardziej sensowne jest prowadzenie działań nastawionych na obie grupy czynników - stresory (zagrożenia) i czynniki salutogenne (Pyżalski, 2010b: 45).

Człowiek i jego miejsce pracy współzależą od siebie. To, jak nauczyciel czuje się w pracy, jest uzależnione od tego, co go w tej pracy spotyka, zarówno w sensie 
pozytywnym, jak i negatywnym. Z drugiej strony to, co człowiek wnosi do pracy osobowość, zaangażowanie, wiedzę i doświadczenie - przekłada się na jakość jego pracy, jak również na instytucję, w której pracuje. W tym kontekście warto przytoczyć dwa zasadnicze podejścia dotyczące zapobiegania wypaleniu zawodowemu powodowanemu zazwyczaj przez silny i długotrwały stres oraz napięcie emocjonalne. Jedno $\mathrm{z}$ nich nazwano podejściem zorientowanym na jednostkę, a drugie podejściem zorientowanym na sytuację (Pyżalski, 2010: 45).

Podejście zorientowane na jednostkę zakłada, że jeżeli chcemy zapobiegać szkodliwemu wpływowi pracy na człowieka lub radzić sobie ze skutkami takiego wpływu, to musi się zmienić sam pracownik. Organizacja (np. szkoła, w której nauczyciel pracuje) ma ograniczony wpływ na to, co będzie się działo z danym nauczycielem. Zatem osoby zarządzające placówką są w tym ujęciu w znacznym stopniu zwolnione $\mathrm{z}$ odpowiedzialności za takie zarządzanie, by środowisko pracy miało możliwie najmniejszy ujemny wpływ na zatrudnione w danym miejscu osoby. W skrajnej sytuacji może to oznaczać postawę zakładającą, że osoba, która sobie $\mathrm{w}$ danym momencie nie radzi $\mathrm{z}$ obciążeniami $\mathrm{w}$ pracy, powinna zmienić zawód lub samodzielnie zintensyfikować swoje wysiłki i „wziąć się w garść”, w taki sposób, by wszystko wróciło do normy. Nawet jeśli podejmuje się jakieś zewnętrzne działania, to i tak ich zasadniczym celem jest zmiana nauczyciela, a nie jego otoczenia (Pyżalski, 2010: 45).

Odmienne jest podejście skierowane na sytuację. Tutaj ma się zmieniać nie jednostka, lecz organizacja, która zatrudnia pracowników. Oczywiście zmiany te koncentrują się na modyfikacji lub całkowitej eliminacji stresorów zawodowych. Jednak to ostatnie jest rzadko możliwe, ponieważ część stresorów (np. kontakt z uczniami przejawiającymi niewłaściwe zachowania) jest na stałe wpisana w wykonywanie zawodu (Pyżalski, 2010: 45).

Koncentracja na strategiach jednostkowych, przy jednoczesnym zaniedbywaniu strategii organizacyjnych, jest bez wątpienia złym rozwiązaniem. Podejście, w którym cała uwaga jest skupiona na czynnikach organizacyjnych, przy braku uwzględnienia poziomu jednostkowego, także ma poważne ograniczenia. Wszystkie nowoczesne ujęcia koncentrują się na obu zarysowanych wyżej obszarach. Oddziaływania i zmiany powinny zachodzić zarówno na poziomie samego nauczyciela, jak i w jego miejscu pracy (np. szkole czy innej placówce oświatowej). W podejściach tych nie chodzi jedynie o to, żeby działać w tych obszarach. Warunkiem koniecznym jest zintegrowanie ich tak, aby realizowane działania były spójne, a tym samym bardziej efektywne (Pyżalski, 2010: 45).

W świetle przedstawionych badań można jednak wziąć pod uwagę skupienie się na strategii skoncentrowanej na sytuacji. Nauczyciele wykazują względnie wy- 
soki stopień umiejętności radzenia sobie w sytuacjach stresowych. Nie wykazują również braku motywacji do pracy czy obniżenia zainteresowania uczniem i jego sprawami. W obecnej sytuacji społecznej warto więc położyć akcent na zmiany w świadomości społecznej dotyczącej wagi i odpowiedzialności związanej z tym zawodem, jak również przemyśleć odpowiednie zmiany organizacyjne dotyczące czasu pracy czy wynagrodzeń adekwatnych do wkładanego wysiłku i zaangażowania.

\section{Bibliografia}

Augustynek A. (2009), Wstęp do psychologii, Warszawa.

Bargiel-Matusiewicz K., Podbielski Z., Klasik A. (2004), Współczesne rozumienie stresu, „Wiadomości Lekarskie", 58, s. 3-4.

Colman A. (2009), Słownik psychologii, Warszawa.

Heszen-Niejodek I., Ratajczak Z. (2000), Człowiek w sytuacji stresu. Problemy teoretyczne i metodologiczne, Katowice.

Korczyński S. (2014), Stres w pracy zawodowej nauczyciela, Kraków.

Łosiak W. (2008), Psychologia stresu, Warszawa.

Mańkowska B. (2017), Wypalenie zawodowe. Źródła, mechanizmy, zapobieganie, Gdańsk.

Merecz D. (2010), Psychospołeczne cechy pracy: stresory i czynniki pozytywne, w: Psychospołeczne warunki pracy polskich nauczycieli. Pomiędzy wypaleniem zawodowym a zaangażowaniem, red. J. Pyżalski, D. Merecz, Warszawa.

Popiel A., Pragłowska E. (2008), Psychoterapia poznawczo-behawioralna. Teoria i praktyka, Warszawa. Pyżalski J. (2010a), Jakie działania można podejmować, by ograniczyć stres zawodowy nauczycieli?, w: Psychospołeczne warunki pracy polskich nauczycieli. Pomiędzy wypaleniem zawodowym a zaangażowaniem, red. J. Pyżalski, D. Merecz, Warszawa.

Pyżalski J. (2010b), Skutki oddziaływania warunków pracy na polskich nauczycieli, w: Psychospołeczne warunki pracy polskich nauczycieli. Pomiędzy wypaleniem zawodowym a zaangażowaniem, red. J. Pyżalski, D. Merecz, Warszawa.

Smoter K., Sury Z. (2017), Walka w ujęciu Karla Jaspersa jako sytuacja graniczna obecna w doświadczeniu nauczyciela. Refleksje na pograniczu filozofii i pedagogiki, „Podstawy Edukacji: Graniczność, Pogranicze, Transgresja”, 10, s. 81-98.

Strelau J., Jaworska A., Wrześniewski K., Szczepaniak P. (2005), CISS. Kwestionariusz radzenia sobie w sytuacjach stresowych. Podręcznik, Warszawa.

Trelak J. (2001), Psychologia stresu, Bydgoszcz.

Zimbardo P.G., Johnson R.L., McCann V. (2010), Psychologia. Kluczowe koncepcje, Warszawa. 
